\title{
Urgensi Pengaturan Tentang Peralihan Hak Atas Merek sebagai Objek Jaminan Fidusia
}

\section{Mohammad Fahrial Amrulla}

${ }^{1}$ Mohammad Fahrial Amrulla; Fakultas Hukum Universitas Brawijaya; Jl. MT Haryono 169; Malang; 65145; Jawa Timur; Indonesia

\section{ART I C LEINFO}

Article history:

Received 2018-10-05

Received in revised form

2018-10-29

Accepted 2018-12-01

Kata kunci: Pengaturan, Merek, Peralihan Hak, Jaminan Fidusia

Keywords: Regulation, Collateral, Right Transition, Fiduciary Collateral
Corresponding Author:

Mohammad Fahrial Amrullah

E-mail address: shaffer.ricky@gmail.com

\section{Abstrak}

Penelitian ini bertujuan untuk mengetahui dan mengkaji pentingnya pengaturan peralihan hak atas merek yang dijadikan sebagai objek jaminan fidusia. Sehingga dapat diketahui bahwa pentingya pengaturan tentang peralihan hak atas merek sebagai objek jaminan fidusia dapat memberikan kepastian hukum bagi kreditur dan debitur serta untuk mengetahui faktor-faktor hukum apa yang menyebabkan peralihan hak atas merek belum bisa diterapkan jika merek tersebut menjadi objek jaminan fidusia. Penelitian ini termasuk jenis penelitian normatif. Dari penelitian yang telah dilakukan diperoleh hasil bahwa secara subtansial Undang-Undang No. 42 Tahun 1999 tentang Jaminan Fidusia maupun Undang-Undang No.20 Tahun 2016 tentang Merek dan Indikasi Geografis belum dapat memberikan kejelasan dalam menafsirkan Pasal 1 angka (1) Undang-Undang No. 42 Tahun 1999 tentang Jaminan Fidusia, maupun Pasal 41 Undang-Undang No.20 Tahun 2016 tentang Merek dan Indikasi Geografis, dan Pasal 499 KUHPerdata.

\section{Abstract}

This study aims to find out and examine the importance of regulating the transfer of rights to the brand that is used as the object of guarantee. So it can be seen that the importance of the arrangement of the transfer of rights to the trademark as the object of fiduciary collateral can provide legal certainty for the creditor and debtor as well as to know what legal factors causing the transfer of the trademark can not be applied if the trademark becomes the object of fiduciary collateral. type of normative research. From the research that has been done obtained the result that substantially Law no. 42 of 1999 on Fiduciary Guaranty and Law No.20 of 2016 on Trademarks and Geographical Indications have not been able to provide clarity in interpreting Article 1 number (1) of Law no. 42 of 1999 on Fiduciary Collateral, as well as Article 41 of Law No.20 of 2016 on Trademarks and Geographical Indications, and Section 499 of the Civil Code. 


\section{Jurnal Cakrawala Hukum, Volume 9 No. 2 Desember 2018}

ISSN PRINT 2356-4962 ISSN ONINE 2598-6538

\section{Latar Belakang}

Perkembangan hukum dan ekonomi pada saat ini telah menyebabkan banyak perubahan pada dunia, pada saat ini $70 \%$ (tujuh puluh persen) porporsi aset dunia adalah aset tidak berwujud atau intangible asset dimana 50\% (lima puluh persen) berupa kekayaan intelektual, bahkan orang terkaya di dunia pun saat ini adalah orang yang memiliki banyak kekayaan intelektual berupa hak cipta, merek, maupun paten yang bernilai tinggi.

Fenomena ini merupakan hal yang tidak pernah diduga sebelumnya oleh para pelaku usaha maupun para pengamat ekonomi. Suatu negara yang tidak memiliki sumber daya manusia dan sumber daya alam dapat menjual benda tidak berwujud berupa berupa kekayaan intelektual ke negara lain dengan nilai tinggi yang mengalahkan nilai benda berwujudnya. Indonesia merupakan salah satu negara pengkonsumsi kekayaan intelektual milik negara lain, hal ini disebabkan karena Indonesia belum banyak memiliki kekayaan intelektual yang bisa dikonsumsi dan digunakan oleh bangsanya sendiri.

Berbagai program pemerintah dijalankan hanya untuk menambah jumlah kepemilikan kekayaan intelektual milik Indonesia. Pada bidang ekonomi Pemerintah Republik indonesia tengah mengambangkan apa yang dinamakan ekonomi kreatif, dimana Badan ekonomi kreatif telah dibentuk dengan Peraturan Presiden Nomor 6 Tahun 2015. Tertulis dalam peraturan tersebut Badan ekonomi Kreatif berkedudukan di Ibukota Negara Republik Indonesia dan berada di bawah dan bertanggung jawab kepada Presiden, merujuk pada hal tersebut dapat kita lihat bersama bagaimana pentingnya ekonomi kreatif bagi pertumbuhan ekonomi di Indonesia, Indonesia akan menjadikan kreatifitas sebagai komoditi yang dapat menopang pertumbuhan ekonomi secara signifikan.

Kebijakan seperti ini tentunya harus didukung dengan peraturan-peraturan yang memadai supaya tidak terjadi sengketa maupun kegaduhan- kegaduhan lain yang dapat timbul di kemudian hari. Ekonomi kreatif berhubungan dengan kreatifitas, sedangkan kreatifitas pasti termasuk pada kekayaan intelektual baik itu paten, merek hak cipta, desain industri, desain tata letak sirkuit terpadu, rahasia dagang, dan perlindungan varietas tanaman.

Sekian banyak kekayaan intelektual, merek adalah kekayaan intelektual yang lain dari pada yang lainnya, merek yang merupakan tanda pembeda suatu produk barang atau jasa menjadi sangat bernialai bagi pemiliknya, merek dijadikan identitas produk barang atau jasa yang memiliki banyak kegunaan bagi pemiliknya, selain identitas merek menjadi cluster atau kasta produk barang dan jasa bagi konsumennya, merek juga menjadi prestige bagi pemilik merek dan juga pengguna merek.

Konsep merek menurut hukum digolongkan sebagai benda bergerak tidak berwujud. Istilah hukum benda adalah terjemahan dari isitilah dalam bahasa Belanda, yaitu Zakenrecht. Dalam pandangan perdata (privatrecht), yaitu hukum harta kekayaan mutlak. Dalam kamus hukum disebutkan pengertian hukum benda adalah keseluruhan dari kaidah hukum yang mengatur hubungan hukum antara subyek hukum dengan benda dan hak kebendaan.

Pembedaan benda yang sangat penting yaitu pembedaan atas benda bergerak dan tidak bergerak serta benda terdaftar dan benda tidak terdaftar. KUH perdata membeda-bedakan benda dalam berbagai macam, yaitu sebagai berikut: Kebendaan dibedakan atas benda tidak bergerak (anroe rende zaken) dan benda bergerak (roerendes zaken) (pasal $504 \mathrm{KUH}$ perdata); Kebendaan dapat dibendakan pula atas benda yang berwujud atau bertubuh (luchamelijke zaken) dan benda yang tidak berwujud atau berubah (onlichme Lijke Zaken) (pasal $503 \mathrm{KUH}$ perdata)

Karena dikategorikan sebagai benda, maka sudah sewajarnya jika benda tersebut memiliki nilai dapat dapat diaikui keberadaannya, oleh s- 


\section{Urgensi Pengaturan Tentang Peralihan Hak Atas Merek sebagai Objek Jaminan Fidusia}

ebab memiliki nilai seharusnya benda tersebut dapat diagunkan atau dijaminkan sebagaimana disebutkan dalam undang-undang kekayaan intelektual yaitu Undang-Undang Nomor 28 Tahun 2014 tentang Hak Cipta, Undang-Undang Nomor 13 tahun 2016 tentang Paten, dan Undang-Undang Nomor 20 Tahun 2016 tentang Merek kesemuanya menyebutkan bahwa hak cipta, paten dan merek dapat dijadikan sebagai jaminan.

\section{Metode}

Jenis penelitian yang akan digunakan adalah Penelitian Yuridis-Normatif. Penelitian ini dilakukan dengan metode Yuridis-Normatif dikarenakan dalam penelitian ini dibutuhkan kajian yang mendalam terhadap sumber-sumber hukum yang mengatur masalah tentang peralihan hak atas merek yang dikategorikan dalam benda bergerak tidak berwujud sebagai objek jaminan fidusia khususnya di Indonesia. Penelitian ini menggunakan jenis pendekatan undang-undang (Statuta Approach) menelaah semua undang-undang dan regulasi yang bersangkut paut dengan penelitian (Marzuki, 2005). Penelitian yang penulis lakukan menggunakan bahan hukum primer, bahan hukum sekunder, dan tersier.

\section{Pembahasan}

3.1. Urgensi Pengaturan Tentang Peralihan Hak Atas Merek Yang Dikategorikan Sebagai Benda Bergerak Tidak Berwujud Yang Digunakan Sebagai Objek Jaminan Fidusia

Merek merupakan benda bergerak tidak berwujud berupa hak maka merek dapat dijaminkan sesuai dengan benda bergerak yang lain walaupun dengan sedikit penyesuaian. Jaminan yang sesuai dengan merek sebagai agunan kredit perbankan maka Jaminan yang sesuai ialah Jaminan Fidusia. Dimana Jaminan fidusia telah digunakan di Indonesia sejak zaman penjajahan Belanda sebagai suatu bentuk jaminan yang lahir dari yurisprudensi.
Bentuk jaminan ini digunakan secara luas dalam transaksi pinjam-meminjam karena proses pembebanannya dianggap sederhana, mudah, dan cepat tetapi tidak menjamin adanya kepastian hukum.

Lembaga jaminan fidusia memungkinkan kepada para pemberi fidusia untuk menguasai benda yang dijaminkan, untuk melakukan kegiatan usaha yang dibiayai dari pinjaman dengan menggunakan jaminan fidusia. Pada awalnya, benda yang menjadi obyek fidusia terbatas pada kekayaan benda bergerkan yang berwujud dalam bentuk peralatan. Akan tetapi dalam perkembangan selanjutnya, benda yang menjadi obyek fidusia termasuk juga kekayaan benda bergerak yang tak berwujud, maupun benda tak bergerak.

Lembaga fidusia muncul dikarenakan ketentuan undang-undang yang mengatur tentang lembaga gadai mengandung banyak kekurangan, tidak memenuhi kebutuhan masyarakat dan tidak dapat mengikuti perkembangan masyarakat. Kelemahan lembaga gadai yang paling utama adalah benda yang dijaminkan harus diserahkan kepada penerima gadai padahal justru benda tersebut penting bagi kegiatan pemberi gadai.

Penjelasan pada paragraf-paragraf sebelumnya telah jelas bahwa dimungkinkan baik perspektif teoritis perdata untuk unsur kebendaan terkait dengan bentuk jaminan untuk agunan kredit perbankan, Internasional dalam ratifikasi organisasi Internasional terkait pembahasan dan pembentukan konvensi bahwa merek dapat menjadi sumber pembiayaan atau agunan (Collateral). Dan setelah mengetahui suatu konsep dasar merek dapat dijadikan sebagai jaminan kredit, tentunya seluruh lingkup kekayaan intelektual seharusnya dapat dijadikan jaminan, baik itu Hak Cipta, Desain Industri, Paten, dan lain-lain.

Kenyataannya secara tertulis dan berdasarkan hukum positif, belum terdapat pengaturan tegas bahwa merek dapat dijadikan sebagai jaminan kredit perbankan. 
Setelah disesuaikan dengan penjelasan sebelumnya bahwa Hukum harus menyesuaikan kebutuhan masyarakatnya. Maka seharusnya merek dapat dijaminkan demi memenuhi kebutuhan masyarakat. Pada kenyataannya masyarakat juga membutuhkan Hak Merek untuk dapat dijaminkan dengan maksud untuk memudahkan masyarakat untuk memiliki modal demi memenuhi kepentingan ekonomi.

Terdapat perbedaan mendasar mengenai Hak Cipta, Hak Paten, Desain Industri yang bersifat rigid dan tidak tergerus oleh waktu, terkecuali adanya masa perlindungan kekayaan intelektual yang dibatasi dalam kurun waktu tertentu. Namun Merek bersifat fluktuatif yang nilainya dapat dipengaruhi dengan hubungan hukum pemegang hak. Misalnya jika debitor dinyatakan pailit, maka merek yang dimiliki oleh debitur akan menurun pula nilainya.

Perbedaan berikutnya ialah dimana hak cipta memiliki hak moral sedangkan hak merek tidak memiliki hak moral yang dapat diartikan bahwa hak merek hanya dinilai dari nilai ekonomi yang dapat diukur dengan ukuran tertentu. maka hak merek lebih khusus mengenai kepentingan ekonomi saja yang lebih sesuai untuk dijadikan suatu jaminan agunan.

Banyaknya aset tidak berwujud berupa merek suatu saat nanti akan menyulitkan pihak kreditur untuk menerima jaminan berupa aset tidak berwujud, dengan demikian kreditur khusunya perbankan akan kesulitan menyalurkan dana masyarakat melalui pinjaman.

Merek memang belum populer dijadikan agunan namun, sebagai prediksi, tuntutan kebutuhan, niaga dan juga tuntutan kebutuhan perbankan dan masyarakat, tampaknya merek yang diagunkan akan menjadi tren lazim dalam praktik di kemudian hari. Hal ini yang menyebabkan perlu diaturnya pengaturan didalam hukum jaminan fidusia khususnya yang mengatur tentang jaminan fidusia berupa benda bergerak tidak berwujud lebih khusus lagi tentang peralihan hak merek yang dijadikan sebagai objek jaminan fidusia.

Pengaturan tentang peralihan hak fidusia khusunya untuk jaminan berupa merek sangat diperlukan pengaturannya, hal ini diperlukan karena belum diaturnya peraturan peralihan hak merek tersebut. Dalam Pasal 41 ayat (1) UndangUndang Nomor 20 Tahun 2016 Tentang Merek dan Indikasi Geografis disebutkan:

Hak atas Merek terdaftar dapat beralih atau dialihkan karena: Pewarisan; Wasiat; Wakaf; Hibah; Perjanjian; atau Sebab lain yang dibenarkan oleh peraturan perundang-undangan. Pada pasal tersebut tidak disebutkan peralihan hak untuk jaminan fidusia, sedangkan peralihan hak pada jaminan fidusia dilakukan diawal perjanjian.

Definisi tentang fidusia menurut ketentuan pasal 1 angka (1) Undang-Undang Nomor 42 Tahun 1999 tentang Jaminan Fidusia pengertian fidusia adalah "pengalihan hak kepemilikan suatu benda atas dasar kepercayaan dengan ketentuan bahwa benda yang hak kepemilikannya dialihkan tersebut tetap dalam penguasaan pemilik benda".

Hubungan Pasal tersebut dengan ketentuan Pasal 33 angka (1) Undang-Undang Nomor: 42 Tahun 1999 tentang Jaminan Fidusia yang menyebutkan "setiap janji yang memberi kewenangan kepada Penerima Fidusia untuk memiliki benda yang menjadi objek jaminan fidusia apabila debitor cidera janji batal demi hukum" sehingga tidak ada titik singgung antara pasal 1 angka (1) dan pasal 33 tersebut atau biasa disebut konflik peraturan.

Penyerahan hak milik dalam jaminan fidusia dikenal istilah constitutum possessorium yang artinya penyerahan hak milik dari debitur kepada kreditur dimana benda yang diserahkan hak miliknya tetap berada dalam penguasaan nyata dari debitur (Masjoen, 1981).

Peralihan hak milik dalam jaminan fidusia digolongkan ke dalam dua aliran yaitu menurut aliran klasik yang menyebutkan bahwa fidusia merupakan peralihan hak milik yang sempurna 


\section{Urgensi Pengaturan Tentang Peralihan Hak Atas Merek sebagai Objek Jaminan Fidusia}

namun digantungkan pada syarat tangguh (opschortende voorwaarde) yang artinya hak milik secara sempurna akan diperoleh saat debitur cidera janji, sedangkan menurut aliran modern peralihan hak milik dalam fidusia bersifat terbatas, sehingga akibatnya hanya melahirkan hak jaminan dan bukan sebagai hak milik (Badrulzaman, dkk, 1991).

Ketentuan batal terhadap setiap janji untuk memiliki benda jaminan (verval beding) merupakan asas yang berlaku secara umum, tidak hanya dikenal dalam Pasal 33 Undang-Undang Fidusia, namun juga dikenal dalam lembaga jaminan lainnya seperti juga Hak Tanggungan (vide Pasal 12 UU Nomor 4 tahun 1996) maupun Gadai (vide Pasal 1154 KUHPer) sehingga tidak mungkin terjadi peralihan hak milik yang sempurna dari debitur kepada kreditur dalam perjanjian jaminan (Witanto, 2015).

Sebagai bukti kita dapat mengambil contoh dalam hal kreditur (penerima fidusia) jatuh pailit, maka benda jaminan fidusia tidak akan masuk kedalam budel pailit, atau dalam hal kewajiban-kewajiban yang timbul atas kepemilikan benda, tidak akan beralih kepada penerima fidusia seperti pembayaran pajak kendaraan yang tetap menjadi kewajiban si debitor meskipun kendaraan tersebut telah menjadi benda fidusia. Hal tersebut menandakan bahwa tidak terjadi peralihan hak milik yang sempurna dalam jaminan fidusia.

Pengakuan hukum terhadap berlakunya hak atas merek sebagai jaminan fidusia. Faktor Ekonomi, tidak semua merek mempunyai nilai ekonomi, merek yang mempunyai nilai ekonomi yang bisa dijadikan jaminan dan mempunyai pangsa pasar (marketable). Dalam perspektif ekonomi, merek mempunyai peluang dan nilai merek dapat dipertanggung jawabkan secara ekonomi.

Masalah yang timbul dititik beratkan pada saat debitur cidera janji, masalah yang timbul adalah masalah peralihan hak merek tersebut, dimana merek tidak ada peraturan yang memfasilitasi untuk pengalihan hak merek tersebut.
Sesuai hasil penelitian dan kajian normatif, ternyata memang sistem peralihan hak merek pada penjaminan fidusia masih mengalami kendala seperti permasalahan di sekitar dasar kepercayaan: penyerahan jaminan yang didasarkan pada kepercayaan tersebut disebut sebagai fiduciare eigendom overdracht. Dasar kepercayaan bagi orang yang beritikad baik tentu tidak menjadi masalah, tetapi bagaimana dengan orang yang beritikad buruk, tentu harus ada mekanisme pengawasan yang tepat dari pemerintah, adanya kesengajaan sebagai perbuatan melawan hukum oleh satu pihak; baik pemberi dan penerima jaminan terutama itikad buruk dari penerima jaminan untuk tidak mendaftarkan.

Di negara bersistem hukum common law tempat asal hukum kekayaan intelektual sudah dapat dilakukan peralihan hak merek yang dijadikan objek jaminan, pertimbangan utamanya adalah dikarenakan merek memiliki nilai jual, dan tidak sedikit merek di negara common law yang memiliki niilai jual yang tinggi.

\subsection{Analisa Kerangka Teori Dalam Pembahasan \\ 1. Teori Kepastian Hukum Untuk Pihak Penerima Fidusia (Kreditur) Pada Jaminan Fidusia Berupa Merek}

Kepastian hukum untuk penerima fidusia atau kreditur sangat diperlukan untuk mengatasi masalah yang timbul dalam sengketa jaminan fidusia dengan jaminan fidusia berupa merek dalam teori kepastian hukum disebutkan bahawa memiliki kepastian berarti memiliki ketetapan dalam pikiran dan bebas dari keraguan. Kepastian hukum secara normatif ialah ketika suatu norma dibuat dan diberlakukankan secara pasti karena mengatur dengan jelas dan logis. Jelas artinya tidak bisa timbul keraguan (multi-tafsir) dan secara logis diartikan bahwa ini menjadi sebuah sistem norma dengan norma lainnya sehingga tidak dapat terjadi benturan atau dapat menimbulkan konflik norma (Marzuki, 2008). 
Kepastian hukum dalam penyelesaian perkara belum tegas diatur tentang peralihan hak objek jaminan fidusia khusunya jaminan berupa hak merek.

Pengaturan tentang pengalihan hak merek sebagai objek jaminan fidusia dalam praktik pemberian kredit memang agak rumit dengan sistem penjaminan lainnya. Sistem penjaminan fidusia yang dijaminkan yaitu kepercayaan dan biasanya benda yang dijaminkan tetap berada dan bisa dinikmati oleh pemberi jaminan. Pada prinsipnya perjanjian fidusia hanya didasarkan pada kepercayaan, tetapi mengandung resiko pada peralihan hak yang dijadikan objek jaminan apabila salah satu pihak tidak beretikad baik.

Pengaturan tentang pengalihan hak merek sebagai objek jaminan fidusia dalam praktik pemberian kredit memang agak rumit dengan sistem penjaminan lainnya. Sistem penjaminan fidusia yang dijaminkan yaitu kepercayaan dan biasanya benda yang dijaminkan tetap berada dan bisa dinikmati oleh pemberi jaminan. Pada prinsipnya perjanjian fidusia hanya didasarkan pada kepercayaan, tetapi mengandung resiko pada peralihan hak yang dijadikan objek jaminan apabila salah satu pihak tidak beretikad baik.

2. Teori Pertanggung Jawaban Hukum Untuk Pihak Pemberi Fidusia (Debitur) Pada Jaminan Fidusia Berupa Merek

Kegiatan pinjaman meminjam uang dengan jaminan fidusia berupa merek tentunya melibatkan pihak peminjam uang yang disebut pemberi fidusia atau debitur, sebagai kreditur yang telah menerima hak berupa pinjaman uang debitur pasti memiliki tanggung jawab berupa kewajiban pengembalian uang pinjaman tersebut sesuai dengan perjanjian fidusia yang telah disepakati konsep yang berhubungan dengan kewajiban yaitu tanggung jawab hukum (liability). Liability dalam pemakaian serta pengertian mengarah pada tanggung jawab hukum. Debitur bertanggung jawab secara hukum dalam perbuatannya sebagai pemberi fidusia dia dapat dikenakan sanksi jika perbuatannya bertentangan atau berlawanan hukum atau tidak memenuhi kewajibannya sebagai debitur. Pada umumnya, sanksi dikenakan terhadap delik karena perbuatannya sendiri yang membuat orang tersebut bertanggung jawab (Asshiddiqie, dkk 2006).

\section{Teori Perlindungan Hukum Untuk Para Pihak Pada Pemberi Fidusia (Debitur) dan Penerima Fidusia (Kreditur) Pada Jaminan Fidusia Berupa Merek \\ Perlindungan hukum menurut Satjipto} Raharjo adalah di mana hukum melindungi kepentingan seseorang dengan cara menempatkan kekuasaan secara terukur untuk bertindak dalam rangka pemenuhan kepentingan tersebut (Raharjo, 1991). Teori ini dapat digunakan untuk kreditur dan debitur pada kegiatan pinjam meminjam yang menggunakan merek sebagai objek jaminan fidusia karena disini kreditur memerlukan kepastian pengalihan hak apabila debitur tidak memenuhi kewajibannya dan begitu pula debitur memerlukan kepastian pengembalian objek jaminan apabila kewajiban pengembalian pinjaman sudah selesai atau lunas.

Menurut Philipus M. Hadjon, perlindungan hukum merupakan perlindungan akan harkat dan martabat serta pengakuan terhadap hak asasi manusia yang dimilki oleh subyek hukum dalam Negara Hukum dengan berdasarkan pada ketentuan hukum yang berlaku di Negara tersebut guna mencegah terjadinya kesewenang-wenangan. Perlindungan hukum tersebut pada umumnya dituangkan dalam suatu peraturan tertulis, sehingga sifatnya lebih mengikat dan akan mengakibatkan adanya sanksi yang harus dijatuhkan kepada pihak yang melanggarnya (Hadjon, 1987). Apabila dihubungkan dengan posisi kreditur dan debitur seharunya debitur dan kreditur dalam hal ini memiliki kepastian yang sama, namun apabila tidak ada 


\section{Urgensi Pengaturan Tentang Peralihan Hak Atas Merek sebagai Objek Jaminan Fidusia}

Mohammad Fahrial Amrulla

aturan mengenai peralihak hak objek jaminan fidusia maka kreditur tidak memiliki perlindungan hukum tersebut, demikian juga apabila debitur telah melunasi kewajiban pinjamannya kepada kreditur namun tidak bisa memperoleh haknya yaitu pengmbalian objek jaminan, maka dalam hal ini kreditur tidak mendapatkan perlindungan hukum.

\section{Simpulan}

Realitas pengakuan hukum terhadap berlakunya hak atas merek sebagai obyek jaminan fidusia dalam praktik belum sebagai jaminan utama, hanya sebagai jaminan pelengkap. Secara subtansial Undang-Undang Nomor 42 Tahun 1999 tentang Jaminan Fidusia maupun Undang-Undang Nomor 20 Tahun 2016 tentang Merek dan Indikasi Geografis belum dapat memberikan kejelasan dalam menafsirkan Pasal 1 angka 2, 4, UndangUndang Nomor 42 Tahun 1999 tentang Jaminan Fidusia, maupun Pasal 41 Undang-Undang Nomor 20 Tahun 2016 tentang Merek dan Indikasi Geografis, Pasal 499 KUHPerdata, sehingga tidak adanya kepastian hukum berlakunya peralihan hak atas merek yang dijadikan sebagai objek jaminan fidusia. Hambatan-hambatan dalam peralihan hak atas merek yang dijadikan obyek jaminan fidusia. disebabkan oleh beberapa faktor hukum dan nonhukum. Faktor hukum, secara yuridis formal belum ada dasar legalitas yang dapat digunakan sebagai rujukan merek sebagai jaminan fidusia maupun peralihan haknya, meskipun hukum positif (ius constitutum) telah mengatur merek sebagai salah satu bentuk benda tidak berwujud dapat dijadikan jaminan fidusia (Pasal 1 ayat 2 UndangUndang No. 42 Tahun 1999 tentang Jaminan Fidusia). Eksistensi Merek sebagai jaminan fidusia belum diakui sebagai acuan para pelaku ekonomi khususnya kreditur atau lembaga fidusia dalam memberlakukan merek sebagai jaminan fidusia, sehingga dalam praktik perbankan belum ada

\section{Daftar pustaka}

Amiruddin, Asikin Zainal. 2006. Pengantar Metode Penelitian Hukum. Jakarta. Raja Grafindo Persada.

Asshiddiqie, Jimlly dan Safa'at Ali. 2006. Teori Hans Kelsen Tentang Hukum. Setjen dan Kepaniteraan Mahkamah Konstitusi Republik Indonesia. Jakarta.

Badrulzaman, Darus Mariam. 1991. Jaminan-jaminan Untuk Pemberian Kredit Menurut Hukum Indonesia. Bandung. Citra Aditya Bakti.

Hadjon, Philipus M. 1987. Perlindungan Hukum bagi Rakyat Indonesia. Surabaya. Bina Ilmu.

Kitab Undang-Undang Hukum Perdata.

Marzuki, Muhammad. 2008. Pengantar Ilmu Hukum. Jakarta. Fajar Interpramata Offsite.

Marzuki, Peter Mahmud. 2005. Penelitian Hukum. Jakarta. Kencana.

Masjoen, Sofwan dan Sri Soedewi. 1981. Hukum Perdata: Hukum Benda. Yogjakarta. Liberty.

Satjipto, Raharjo. 1991. Ilmu Hukum. Bandung. Citra Aditya Bakti.

Soerjono, Soekanto dan Mamudji Sri. 2003. Penelitian Hukum Normatif: Suatu Tinjauan Singkat. Jakarta. Raja Grafindo Persada.

Soerjono, Soekanto. 1986. Pengantar Penelitian Hukum. Jakarta. UI Press.

Sunggono. 2007. Metodologi Penelitian Hukum. Jakarta. Raja Grafindo Persada.

Undang Undang Dasar Negara Republik Indonesia Tahun 1945.

Undang-Undang Nomor 20 Tahun 2016 Tentang Merek.

Undang-Undang Nomor 42 Tahun 1999 Tentang Jaminan Fidusia.

Undang-Undang Nomor Nomor 10 Tahun 1998 Tentang Perubahan Atas Undang-Undang Nomor 7 Tahun 1992 Tentang Perbankan.

Witanto D.Y. 2015. Hukum Jaminan Fidusia dalam Perjanjian Pembiayaan Konsumen (Aspek Perikatan, Pendaftaran, dan Eksekusi). Bandung. Mandar Maju. 